\title{
DÜBLIN
}

Technological University Dublin ARROW@TU Dublin

2009-01-01

\section{The Civilizing of Hurling in Ireland}

\author{
Paddy Dolan \\ Technological University Dublin, paddy.dolan@tudublin.ie \\ John Connolly \\ Dublin City University, John.Connolly@dcu.ie
}

Follow this and additional works at: https://arrow.tudublin.ie/clsart

Part of the History Commons, and the Sociology Commons

\section{Recommended Citation}

Dolan, P. \&Connolly, J. (2009) The Civilizing of Hurling in Ireland. Sport in Society, vol.12, no.2, pp.

196-211. doi:10.1080/17430430802590995

This Article is brought to you for free and open access by the Centre for Consumption and Leisure Studies at ARROW@TU Dublin. It has been accepted for inclusion in Articles by an authorized administrator of ARROW@TU Dublin. For more information, please contact arrow.admin@tudublin.ie, aisling.coyne@tudublin.ie, gerard.connolly@tudublin.ie.

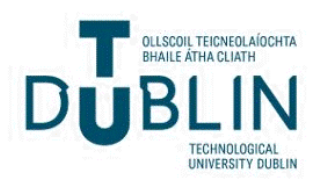


Authors: $\quad$ Dolan, Paddy and Connolly, John

Title: $\quad$ The civilizing of hurling in Ireland

Originally published in Sport in Society, Vol. 12, No. 2, March 2009, 196-211. Copyright Taylor \& Francis.

The publisher's version is available at:

http://www.informaworld.com/smpp/content $\sim \mathrm{db}=\mathrm{all} \sim \operatorname{content}=\mathrm{a} 908731870$ ? waited $=0$

Please cite the publisher's version:

Dolan, Paddy and John Connolly (2009) 'The Civilizing of Hurling in Ireland', Sport in Society 12(2): 196-211.

ISSN 1743-0437 print/ISSN 1743-0445 online

DOI: $10.1080 / 17430430802590995$

This document is the author's final manuscript version of the journal article, incorporating any revisions agreed during peer review. Some differences between this version and the publisher's version remain. You are advised to consult the publisher's version if you wish to cite from it.

Copyright (C) and Moral Rights for the papers on this site are retained by the individual authors and/or other copyright owners. 


\title{
ARTICLE
}

\section{The civilizing of hurling in Ireland}

\author{
Paddy Dolan \\ Dublin Institute of Technology, Dublin, Ireland \\ John Connolly \\ Dublin City University, Dublin, Ireland
}

\begin{abstract}
This essay examines the sport of hurling in Ireland through the theoretical framework of sport and leisure developed by Elias and Dunning. Through an analysis of newspaper reports of games, of rulebooks and codes of play, as well as historical data on increasing social differentiation and integration, we argue that hurling has undergone sportization and civilizing processes. However, due to the unevenness of wider figurational shifts these processes have been non-linear and fragile. Gradually, we see increasing numbers of rules, as well as increasing severity of punishment for the breaking of specific rules relating to violent play. The level and extent of violent conduct also appears to change with both players and spectators becoming more self-controlled. The increasing emotional restraint of spectators and players can be explained by the changes in the overall structure of Irish society during this period, particularly from the 1960s onwards with increasing interdependencies between people.
\end{abstract}

\section{Introduction}

The purpose of this essay is to demonstrate the applicability of the figurational approach to the Irish national game of hurling. We argue that though the balance of tensions between social and self steering on the part of players and spectators moves in the latter direction over time, this change has been somewhat fragile and limited precisely because of the complex, contradictory and uneven nature of figurational dynamics in Ireland (and between Ireland and Britain) over the past 140 years.

Hurling is a field game of 15-a-side played with broad, flat wooden sticks (hurleys) and a small ball (sliotar). Unlike field hockey, the game is played both on the ground and 'in the air'; the ball can be propelled large distances through the swinging action of the player with the hurley. The ostensible object of the game is to accrue scores through propelling the ball between goalposts, either under the bar to score a goal (worth three points) or over the bar to score a single point. The goalposts resemble the $\mathrm{H}$ structure of rugby, and each team has a goalkeeper. It has a long history in Ireland, though its precise form has changed over time. The goal of this essay is to trace the major changes of the game since its first written codification in the late nineteenth century. Such rule changes reflect the changing expectations of players and spectators alike and, more generally, the shifting taste for displays of open violence. We contend, in support of Elias and Dunning, ${ }^{1}$ that over 
time players and spectators have adjusted their conduct and gradually exercised a higher degree of self-restraint in their enjoyment of games. However, occasional transgressions of narrowing limits of permissible physical confrontation continue to occur, though these are now subject to increasing social scrutiny and reprimand. The behaviour of spectators has become more clearly civilized (in the technical sense as used by Elias), in that spontaneous displays of aggression towards players, officials and opposing supporters have declined. We contend that these changing thresholds of violence have occurred within the context of the standardization of the written rules of the game (the 'sportization' of hurling), and within a broader context of increasing social interdependencies beyond the field of play. The essay shows various aspects of these intertwined social processes - the convergence of rules; increasing social coordination around the scheduling and completion of match fixtures; the advancing threshold of repugnance concerning overt displays of violence; the shifting power ratios between players and governing officials; spectator self-control; and the shifting figurations comprising people in Ireland. These aspects will be discussed in turn.

\section{Rule convergence and game standardization}

The main organizational basis for the nascent standardization of the game of hurling began with the establishment of the Gaelic Athletic Association (GAA) in $1884 .^{2}$ At this time there was still much confusion between players of the game in different regions of the country, but gradually with the formation of written rules and arrangement of game fixtures between geographically dispersed teams, a more common game began to emerge. There had of course been a game called hurling in Ireland for many centuries - one that could be considered functionally equivalent to the folk football of various British towns and parishes prior to the codification of football or soccer in England during the nineteenth century. ${ }^{3}$ But the game differed significantly from place to place, and it seems to have been played on an occasional basis for prizes or parish and town pride against neighbouring districts. The specific rules were probably agreed on a game by game basis around the generally accepted parameters of local tradition. The earliest evidence of written rules appears to be the Killimor rules of 1869 for a club based in Ballinasloe in the West of Ireland. ${ }^{4}$ The confusion of earlier games is evident in the attempts by the rule framers to legislate for 'the future' and distinguish between competing teams: 'That for the future that not less than thirty be accepted to hurl a challenge match'; 'That to avoid mistakes our hurling colours for the future be green and gold' ${ }^{6}$ Though there was to be a minimum requirement in terms of the number of players, this had obviously not necessarily been the case previously. Also, much local contingency remained in terms of the actual maximum number that would play. 'Challenge' matches were occasional and not part of a scheduled structure of games that pertains to a league for example. It would seem that prior games were prone to confusion not only in terms of the number of players that should play, but also their membership of specific teams; the club chose particular colours in order that effective team play could advance: the greater the distinction between 'them' and 'us' the more likely that passing interchanges and reciprocal movement for advantageous positions on the field of play could occur. Before each game the duration or total number of goals to be played was agreed by the captains of both teams, ${ }^{7}$ indicating that aspects of each 
game were negotiated on a local, immediate basis (there was little tradition of simply playing the game according to well established, stable and inflexible rules).

Attempts were made to establish new hurling clubs in the capital, Dublin, from the early 1880s, but these were often short-lived. ${ }^{8}$ In April 1884, prior to the establishment of the GAA later that same year, Michael Cusack (GAA's founder) brought his Metropolitan Club from Dublin to play Killimor in Ballinasloe. Though there was prior agreement on rules, the match was soon abandoned due to confusion over rules, continued interference by spectators and 'rough' play. ${ }^{9}$ Cusack complained in the then upper- and middleclass unionist newspaper, The Irish Times, that Killimor 'slashed in a reckless and savage manner'. ${ }^{10}$ As Mandle notes, 'Not until teams from different areas met would differences in rules become apparent'. ${ }^{11}$ This realization led to attempts to standardize the rules of the game, so that hurling could become a truly national sport. Each team had to adjust their accustomed tradition of play in accordance with the traditions of potential opposing teams. Though such attempts were routinely made, initially they met with little success because players reverted to their learned 'second nature' rules of play in the context of game-contests. Gradually, the centralized organization of the GAA was able to impose relative discipline through rule standardization, more consistent rule implementation, neutralization of referees and other disciplining social functionaries, surveillance and bureaucratization of rule transgression, and the learning by players themselves of the consequences of such transgressions. In the early years of the GAA the organization of games was often precarious; teams frequently arrived late, even for All-Ireland Finals. The difficulty in coordinating fixtures meant that there was considerable flexibility in the number of players permitted in each team; the GAA rules of 1884 allow for between 14 and 21 players aside. $^{12}$ Michael Cusack founded The Celtic Times to promote the game, but often reported on the inadequate nature of playing in the early years. He complained of the lack of spectators at a game in 1887 where, 'there were at times during the contest a half-dozen of the hurlers lying with their faces on the ground resting themselves, while the side-your-own system [play according to your own rules] was in full operation'. ${ }^{13}$ So the absence of enforced standardized rules tended to result in violent play or a practical withdrawal from play. On this occasion the lack of spectators no doubt pushed the outcome in the latter direction.

In 1893, the GAA secretary noted the difficulty in organizing games as sides often neglected to turn up for the fixtures. ${ }^{14}$ It was not until 1910 that the scheduled games were actually played within the year of the designated national championships. ${ }^{15}$ In 1895 , the rules specified that the number of players aside should be $17,{ }^{16}$ thereby reducing the local negotiation and interpretation of the rules somewhat. There were evidently difficulties in maintaining this stipulation however, as the rules of 1909 allowed a match to be started with as few as 13 players aside. ${ }^{17}$ The 1915 rules specified that though a match may start with 13 aside, for inter-county games the second half could not be resumed without $15 .^{18}$ So there were continued attempts at standardizing the number of players (and therefore the structure and flow of the game itself), but within the then acceptable standards of tardiness prevailing in broader Irish society at the time. Elias notes that as societies become more 
functionally complex and as social interdependencies increase and intensify there is growing pressure to be on time, which in effect means adjusting one's conduct to enable the reciprocal performance of inter-related functions. ${ }^{19}$ However, such a culture of punctuality requires time to become established and varies according to the specific density of the social networks within which each individual is socialized. In social networks of relatively short links of interdependencies, the pressure to be punctual is less pressing; in turn, it is difficult to impose such standards on people attuned to a more autarkic social life. The culture of timing and scheduling of events had become more advanced by the framing of the 1943 rules, when the postponement of matches seven days hence was prescribed. ${ }^{20}$

Organization of games was further hampered (and in other respects advanced) by escalating hostilities between Irish republicans and British forces (which included Irish members of the police and defence forces) during the War of Independence of 1919-21, and within the Irish revolutionary movement during the Civil War of 1922-3. Many parts of the country were placed under military rule in 1919, which included the need for movement permits. ${ }^{21}$ Transport lines and systems were destroyed or hampered for militarily strategic reasons, ${ }^{22}$ but this had the unintended consequence of limiting the movement of players and spectators alike to various pitches around the country. We see here the interdependence between political and leisure processes within the same figuration (mutually dependent network) of people occupying the same territory; the 'production and consumption' of games, as leisure pursuits, depend upon a relatively pacified social space which in turn depends upon state monopolization of the means of physical force. ${ }^{23}$

The sport also underwent a rationalization process in terms of the commencement of each match. Initially all players except the goalkeepers lined out in the centre of the pitch before the ball was thrown in. This was gradually reduced to two from each side by the 1966 rules, suggesting the heightening significance of structural positions on the field of play. With all players along the same line of play, a fortunate movement of the ball would open up the pitch for a swift attack on the goal with only the goalkeeper to pass. The maintenance of positions from the beginning reduces this element of luck. Of course the significance of winning the ball from the start in the early rules probably heightened the tensions between opposing players, leading to more extreme use of physical force. As we shall see in the following section, the game also underwent civilizing (and sportization) processes in respect of the tolerable threshold of violence on display.

\section{Thresholds of violence}

While it is difficult to be certain that violence has actually declined in the sport of hurling, ${ }^{24}$ we can state with considerable confidence that the "threshold of repugnance ${ }^{25}$ towards displays of violence advanced. This means that games came under greater scrutiny and surveillance in an effort to discipline players and implement the developing standards of fair play. This change is most evident in rule changes, but is also clear from newspaper reports and expressions of opinion regarding the game, as well as letters between hurling advocates. From the earliest Killimor rules players were expected to exercise some control over themselves regarding the use of physical force. But these standards of aggression control 
were relatively modest; for example, the 1869 Killimor rules called for: 'Three umpires to be appointed on each side who have power to order any hurler to cease playing, who in their opinion is under the influence of strong drink, who loses his temper or strikes any of his opponents intentionally. 26

At this time the rules were not applied by neutral social functionaries but by partial observers, and the lack of 'mutually expected self-restraint ${ }^{\text {'2 }}$ regarding the use of aggression meant that three umpires for each team were appointed. Obviously, player drunkenness at matches was at least frequent enough to warrant the inclusion of a rule prohibiting such conduct. The rule against striking emphasizes the affective rather than instrumental use of violence; ${ }^{28}$ it was envisaged that players might resort to violence out of temper (loss of self-control) but less likely to do so in pursuit of strategic advantage. That some versions of the game were more violent before the establishment of the GAA is clear from the Laws of Hurley (1870) which was played in Trinity College Dublin: "No Hurl to be shod with iron, or hoped with wire in a dangerous manner'. ${ }^{29}$ The GAA rules did not make reference to wire or other metal components of the hurley stick, which indicates a relative pacification of the game as promoted by the GAA. Nevertheless, the use of three-foot wooden sticks to propel the ball still constituted a potential for very dangerous play. While the rules forbade the 'intentional' striking of an opponent with the hurley, it was expected that the game be played in a 'manly' fashion. Indeed the game in its infancy as an organized sport was juxtaposed at the time against the less masculine leisure pursuits of the British, and particularly the English; Archbishop Croke wrote to Michael Cusack in 1884 accepting the offer to become patron of the GAA:

We have got such foreign and fantastic field sports as lawn tennis, polo, croquet, cricket and the like - very excellent, I believe, and health-giving exercises in their way, still not racy of the soil, but rather alien . . . if we continue travelling . . putting on, with England's stuffs and broadcloths, her masher habits and such other effeminate follies as she may recommend, we had better, at once, and publicly abjure our nationality, clap hands for joy at sight of the Union Jack, and place 'England's bloody red' exultantly above the green. ${ }^{30}$

So the symbolic and social distinction between English and Irish groups, colonizer and colonized, moderated the parallel social process of declining physical violence in national sport, especially hurling. Unlike organized sports in England, which had largely replaced the military preparatory function of earlier forms with a more mimetic tension, ${ }^{31}$ the development of Irish national sport was still at this point emphasizing its military character. For example, a journalist with The Celtic Times, probably Michael Cusack, ${ }^{32}$ describes the scene before a county championship match as follows:

Shortly before one o'clock, the vast army of Gaelic soldiers [players] - with their numerous sympathisers - assembled in the O'Connell Square, and with discipline that would do credit to experienced and well-trained men, formed themselves into battalions and marched in their picturesque costume and carrying their camáns [hurley 
sticks] on their shoulders to the scene of action. Their sturdy and resolute appearance affrighted the timid knot of self-important disciples of the foreign faction who peered from behind the curtains at the steady step of their triumphant foes, who are ready to take up arms at a moment's notice to fight for the supremacy of their respective parishes. $^{33}$

The native game of hurling was juxtaposed against foreign (British) games such as soccer, cricket and rugby. As part of this relational dynamic the followers and players of the opposing games were also juxtaposed in terms of strength and willingness to defy ostensible authority. The 'timid' disciples of British rule betray their lesser sense of wegroup belonging ${ }^{34}$ to the outsider group (in the context of the established Anglo-Irish gentry and nobility) who have positioned themselves against continued international integration (through the United Kingdom of Great Britain and Ireland) in favour of a rising feeling of pride connected to national (specifically Irish) distinction. This defiance was related to the relative success of land agitation struggles from the 1880s onwards that reflected the shifting power relation between tenant-farmers and landlords in favour of the former. ${ }^{35}$ The use of physical force in these conflicts underpinned the social acceptability, and indeed necessity, to display aggression in other contexts, such as sport. There were of course always limits to the acceptability of violence, but the prevailing culture of violence at this time can be characterized as ambivalent; it was understood that people may resort to violence to protect property or to attack opponents, and this disposition, or habitus, ${ }^{36}$ could spontaneously emerge during games of conflict. The ambivalence towards violence was partly connected to the felt need to defy the derogatory characterizations of the national we-group by the established colonizers. Hence, hurling was described by Cusack and others as 'rational' and 'scientific', while on other occasions lauded as militaristic and dangerous. Cusack, in writing of a hurling match between parishes, declared that 'a more powerful or muscular body of men I have never seen. They were certainly in fighting form, and, with their huge braces and belts strapped around their waists, they looked as if they were cast in a fighting mould. ${ }^{37}$ These men were obviously valorised for their muscularity and readiness for physical violence in the name of nationhood, a conclusion that McDevitt also reaches. ${ }^{38}$ Cusack responded to the charge that hurling was dangerous with defiant pride in the aggressive nature of the sport: 'It is the most dangerous game ever played on this planet. The game was invented by the most sublimely energetic and warlike race that the world has ever known. ${ }^{39}$

The ambivalence towards 'rationality' can be seen in the attitude expressed towards emotional spontaneity and its assumed relationship to personal character at this time: 'He who is passionate and hasty is generally honest. It is your old dissembling hypocrite of whom you should beware. There's no deception in a bull dog. ${ }^{40}$ Of course, the fact that Cusack refers to 'dissembling' means that there were people of his acquaintance that were capable of adjusting their statements and convictions according to social circumstance, but this 'trait' is positioned in opposition to the true Gael devoted to the emerging national sport of hurling. This attitude reflects his own social trajectory from a modest west of Ireland farming background to first teacher and then owner of an academy in Dublin. ${ }^{41}$ The positive value attached to emotional spontaneity and volatility was also displayed in match 
reports; when one player "was made to kiss mother earth by an opponent . . . [his] anger having risen to a high pitch, he called the cithogue [left-hander] into requisition', whereupon the opponent "presented the right cheek whereon to smite him . . . and the two Gaelic boys were in a moment perfect friends again'. ${ }^{42}$ Not only was emotional volatility valued by observers, but it was also practiced by players of the game. This was not merely characteristic of the sport but also related to the general volatility of life in late nineteenth-century Ireland. The GAA had quickly fragmented into opposing factions; when Cusack attempted to attend the 1887 GAA convention he was physically threatened by members of the executive and a pistol shot was fired at him as a warning. ${ }^{43}$

The advancing repugnance to displays of overt violence on the field of play is evident in the need to instruct players not to 'butt with the head' in the 1889 rules. ${ }^{44}$ Players seem to have had a higher pain threshold, which is in keeping with a more violent game; one team in the 1889 All-Ireland senior hurling final played in bare feet due to a waterlogged pitch, ${ }^{45}$ a feat repeated by another team in the 1891 final. ${ }^{46}$ The 1897 rules attempted to improve the social scrutiny of rule transgressions by compelling referees to submit reports of 'rough play' to central authorities and to ensure that 'no nails, spikes, or iron tips [were] on the boots of the players', but the need to prohibit head butting and 'charg[ing] from behind' remained. ${ }^{47}$ In fact, the prohibition against head butting remained until $1950 .{ }^{48}$ Reference to striking with the head returned in 1986 and remained up to the current rules, ${ }^{49}$ but this is in the context of a general rule on striking, prohibiting players from 'striking or attempting to strike an opponent with a hurley, head, arm, elbow, hand, or knee'. However, it does appear that some players occasionally transgressed the taboo on head-butting; for example in 1977 a player was sent off for 'butt[ing] in the face' during a provincial inter-county hurling final. ${ }^{50}$ This indicates a fragile internalization process regarding socially acceptable conduct and the fact that selfrestraint on violent play could break down in the context of the cumulative escalation of 'rough' play between opposing players when not adequately subjected to social scrutiny by referees. That being said, head-butting in hurling seems to have become a rare occurrence at least at the inter-county level of competition. While we argue that the sport has become more civilized in this respect, we do not see this as a linear development nor one immune from reversals and breakdowns.

In 1897, players could be suspended for a year for threatening the referee. The logic of such prohibitions and social monitoring was that these practices had occurred at the time. It is likely that the greater sanctions and responsibilities at the disposal of the referee initially heightened player antagonism towards him; previously, players had less rules and rule implementation to contend with. The social functionary charged with reducing the violent conduct at games would initially become the focus of players used to relatively freer expression of aggression in the context of a game-conflict with considerable potential for inflicting physical harm on opposing players. An individual player was not only under social pressure from the referee to place limits on his aggression, but also from the entire team itself. The rules of 1897 allowed for the suspension of the whole team should any player threaten the referee, while the same sanction applied in the 1910 rules for 'rough play' ${ }^{51}$ From 1909, goalkeepers were increasingly protected from players charging at them 
when they were not in possession of the ball. The advancing threshold of repugnance towards violent displays did not proceed smoothly nor in a unilinear direction. As the escalating conflict between Irish nationalist groups on the one side and English and Irish unionist groups on the other become more pronounced during the second decade of the twentieth century (and the ethos of violent confrontation for political ends became more acceptable), the organizers of the sport made reference to the military function of hurling. In 1911 a future president of the GAA stated: 'We want our men to train and to be physically strong so that when the time comes the hurlers will cast away the camán for the steel that will drive the Saxon from our land. ${ }^{52}$ The military allusions of hurling tended to mirror the social tensions between two competing group identifications. As the tensions rose, hurling's mimetic function subsided and it was presented as an actual preparatory ground for military conflict. These were not mere allusions; the British state, who had rarely if ever exercised a monopoly on the means of physical violence in Ireland, were faced with declining control over violence from this period. Social groups advocating a separately governed territory of Ireland trained for imminent armed conflict with hurley sticks, and Croke Park, a site of GAA matches, became the focus of a revenge attack by British State forces in 1920, causing the deaths of one player and twelve spectators. ${ }^{53}$ A county branch of the GAA in 1913 endorsed a motion to establish rifle clubs to train an army. ${ }^{54}$

At this time, hurling games could be abandoned due to player violence, as occurred in the 1915 Munster (one of four Irish provinces) semi-final. $^{55}$ Player violence and spectator violence tended to be inter-related in that the latter often followed the former up to the 1960s. The 1933 Munster hurling final included fights between players and the striking of one player with a hurley stick, which led to 'a pitched battle with upraised hurleys, swinging dangerously at one another' ${ }^{56}$ The 1936 All-Ireland semi-final finished abruptly when one team walked off the pitch in response to one of their players being injured in a 'fracas'. 57 During the game, 'There was a penchant to draw wildly and players suffered minor injuries as a result. . . . Even when the ball was not in their immediate vicinity players were often vigorously tackling each other unnecessarily. ${ }^{58}$ The emphasis on the latter journalistic comment may indicate that this was unusual and/or exciting, but the critical assessment of player conduct is based on the futility of the violence in respect of its instrumentality. The moral denunciation of players is muted by comparison. Journalists characterized both these matches in the 1930s as 'exciting' specifically in regard to the moment when violent conflict arose on the field of play. While the 1933 game was described as 'unpleasant', the players were not described in terms of individual or group disgrace. By contrast, the action of the spectators who invaded the pitch was characterized as 'disgraceful', suggesting a higher standard of spectator self-control than player self-control at this time.

Gradually, however, players were expected to exert greater self-control. This no doubt was connected to the increasing levels of social control and observation of players by functionaries charged with regulating the displays of aggression on the field through the exercise of sanctions. As discussed above, from 1950 the rules do not include a prohibition on head butting nor the wearing of boots with nails, spikes or iron tips. ${ }^{59}$ This 
indicates that these practices had become so taboo that they did not need to be explicitly stated any longer. The development of the national habitus precluded the active desire to cause serious injury to opponents. From 1973 the referee was expected to consult with linesmen and umpires for the infringement of rules, and players could be cautioned for striking the goalposts with the hurley, ${ }^{60}$ requiring players to monitor and control their emotional urges, such as anger or frustration, to a much higher level. In the same year the rules state, 'Pushing in the back, even with the chest, is a foul', increasing the demands on players to control their conduct on the field. The 1975 rules extend the prohibition on intentional striking of another player with the hurley to include bringing the hurley 'through careless play in contact with the person of another player', ${ }^{61}$ so that players not only were expected to refrain from deliberately striking another, but also to be continually cognizant of their position on the field in relation to nearby players. The greater 'wildness' of earlier play was increasingly restricted; players had to think about the potential injurious consequences of their use of the hurley stick prior to any attempts to propel the ball or secure its possession.

These rule changes are not merely bureaucratic of course; they reflect changing norms and values concerning how the game should be played and in particular the degree to which aggression should be released or constrained, and the balance expected between social and self-control in the exercise of that constraint. As the game became less dangerous, and to some extent initially less exciting, commentators adopted a more reflective appreciation of the sport's skills. A journalist described the 1974 All-Ireland semi-final as 'lacking bite', but 'enjoyable for those who enjoy the spectacle of master craftsmen forging scores'. ${ }^{62}$ This is not to suggest that the sport became devoid of physical aggression. The game still involved the propulsion of a small ball through the air at high speed with the use of broad wooden sticks; occasional injuries were inevitable. Tensions between opposing players could still lead to aggressive confrontation, but they were increasingly subject to social observation and scrutiny not only by referees and umpires, but also special adjudication panels who could view video footage of games. For example, two players were sent off shortly after the start of the 1998 Munster final 'for a serious exchange of blows', ${ }^{63}$ while others were subsequently subjected to a Games Administration Committee which viewed video evidence of the incident. Moran later partly attributed the outbreak of violence before the game started to the referee leaving the field of play, ${ }^{64}$ indicating that in conditions of imminent sporting conflict with group pride at stake, player self-control can diminish in the absence of effective social control. So while the expectations of limited aggression, and the degree of social observation, increased over the course of the twentieth century, the inter-team tensions remained strong. Consequently, player self-control on the field continued to be somewhat fragile. The need 'to stand your ground' against threats and intimidation from an opposing player in a sport that structurally developed into an inter-related chain of dyadic contests on the pitch meant that spirals of violence could erupt rapidly if unchecked by social observation and potential sanction. The public attitude to displays of violence also became less forgiving over the twentieth century. Journalists were more willing to name players who engaged in violent conduct in their reports, ${ }^{65}$ compared to newspaper reports of the 1930 s for example which tended to refer to a player only in terms of his team. Even referee reports of this earlier period demonstrate a lenient tone. The report of a 1946 inter-county game included details of two 
named players who were sent off for striking each other with their hurleys; in his report (to be viewed by GAA Central Council only), the referee states: 'I sent them to the line but I will now ask the Central Council member to deal lightly with those boys. I think if they were warned to control themselves in future it would meet their case. ${ }^{, 66}$ According to a hurling referee of the 1940s and 1950s, speaking in 2002: 'Hurling in those days was much tougher than it is now . . . There was far more aggression in the game then. ${ }^{67}$

The social desire to diminish the displays of overt aggression is also clear from the introduction of helmets in the 1970s on a voluntary basis, and the compulsory wearing of helmets for players under the age of 21 from $2005 .{ }^{68}$ Of course, headgear does not necessarily abolish injury but it does significantly reduce the display of blood. ${ }^{69}$ McIntyre compares player safety concerns in the 1980s with the relative tolerance of injuries by players in the 1950s, "when men were tougher, and were not in the least perturbed by the sight of blood "pumping" from a gaping head wound. But times have changed., 70

Though the growing social constraint towards self-constraint on the field of play has not proceeded smoothly, this process has been more evident in relation to the conduct of crowds at matches.

\section{Spectator involvement and detachment}

The behaviour of spectators at matches has been interdependent with that of players, but the precise nature of crowd responses to player conduct has changed considerably over the course of the twentieth century. In the early decades of the standardization of hurling and the GAA organization, spectator interference with play and crowd encroachment or invasion of the pitch were quite common. As the century progressed, match crowds became less directly involved in the game, i.e. more detached, and the emotions of the game were increasingly experienced through the eye. ${ }^{71}$ However, this shift did not occur significantly until the 1960s, and there were different forms of spectator involvement undergoing changes since the standardization of the game in the late nineteenth century. The Killimor rules of 1869 declared:

Bystanders to have no voice in any decision, and should they interfere with the hurlers in any way, that may be considered by the umpires and judges as preventing the game being fairly played, the aggrieved hurlers may claim the prize. ${ }^{72}$

Since the foundation of the GAA, with its strict amateur ethos, the emphasis on prizes disappeared in the rules, but the concern with spectator interference did not. As discussed in the above section, initial attempts to popularize and standardize the game, through exhibition matches, were hampered by spectators encroaching on the pitch: the exhibition match between Cusack's Metropolitans and Ballinasloe's Killimor team resulted in repeated pitch invasions. ${ }^{73}$ The 1886 GAA rules conferred on the referee the power to award a score if a shot destined for the goal 'had not struck a bystander', ${ }^{74}$ indicating that spectators were prone to attempts at diverting the trajectory of shots. Supporters of course did not continuously impede play during games, for in such circumstances any game 
at all would become virtually impossible, but the generally participative nature of their attendance at matches is clear from Cusack's complimentary remarks of a crowd at a county championship match:

The spectators behaved splendidly. They, to a man, kept behind the ropes, and never in the least interfered with the hurlers. This is certainly to be commended, and the spectators in the other places at which I have been present might, with advantage, follow the example of these orderly, and, at the same time, highly enthusiastic crowd of 15,000 people. $^{75}$

The 1897 GAA rules empowered the referee to terminate the game due to interference of spectators', and clubs were expected to take precautions 'to prevent spectators threatening or assaulting referees, officials, or players, during or after matches' ${ }^{76}$ Violence amongst spectators or between players and spectators was often directly related to violence on the field. For example, the Munster final of 1933 was terminated early by the referee with the game awarded to one of the teams when a 'melee' amongst the players led to a pitch invasion 'with crowd from the sidelines joined in the encounter, camáns and fists being used. The row was soon stopped, but the pitch could not be cleared of the crowds. ${ }^{, 77}$ A journalist referred to 'the most disgraceful and unsporting action of a certain section of the crowd' and the fact that the supporters were 'attempting to stave off inevitable defeat'. ${ }^{78}$ So at this time both players and spectators alike struggled with the value of 'fair play'. Supporters disrupted matches that their team were in danger of losing. Supporters also interfered with the progress of matches for more spontaneous reasons - usually due to injuries suffered by players. The 1936 AllIreland semi-final was disrupted by a pitch invasion following one such incident, ${ }^{79}$ and the aggrieved team refused to resume the match when an opposing player was not dismissed by the referee. When the pitch was eventually cleared of spectators, and one of the teams had walked off, the remaining team cheered, leading to another immediate pitch invasion. Displays of emotion were directly interdependent on the figuration of opposing players and supporters. High levels of emotional involvement and behavioural response operated according to a 'vicious circle' or 'double bind', ${ }^{80}$ from which each group had difficulty escaping.

The 1945 rules recognized the need for excitement of spectators; referees were instructed, 'Always keep the game going by prompt decisions - the spectators enjoy such' ${ }^{81}$ Prompt decisions would allow the play to flow, for frees to be awarded quickly, and for offending players to be dismissed if necessary, which could diminish the likelihood of the crowd 'taking the law into their own hands'. But rule changes did not immediately produce changes in the conduct of crowds at matches. During the closing stages of the 1950 Munster final supporters ran on to the pitch to celebrate scores, even though this spontaneous reaction hampered their team's chances of success. ${ }^{82}$ There was a large-scale pitch invasion, but this occurred once the game had finished, and the referee had to be escorted from the pitch by policemen. The journalist also reported fighting in the crowd between opposing supporters, while one player had been attacked by a spectator during the game. Supporters still expressed their excitement or indignation with brief pitch incursions but these gradually became less 
frequent and violent. The GAA authorities became more successful in controlling the crowds through effective deployment of stewards at pitch-side. We argue that displays of violence by spectators also became increasingly socially unacceptable, and even spontaneous feelings of joy became relatively restrained in that on-pitch celebrations were postponed until after the game concluded. Even those few who indulged in physical violence towards the referee postponed their displays of aggression until the end of the match.

Inter-county matches since the 1960s have been relatively free of direct spectator involvement. There have been exceptions, such as the reported incident of a section of the crowd throwing plastic bottles and tin cans onto the pitch in response to a player being booked during the 1989 Munster final between Waterford and Tipperary. ${ }^{83}$ But this conduct is more detached, and more concerned with avoiding injury or detection, than invading the pitch and assaulting players or officials directly. The crowd behaviour was dependent upon events on the field of play, as the team they supported were suffering a heavy defeat. This response is connected to feelings of 'group disgrace' at losing again in the provincial championship (Waterford had only been Munster champions five times compared to Tipperary's 35), and also to the conduct of their team's players, who, according to Downey, had engaged in 'an appalling display of bad sportsmanship' through dangerous play. ${ }^{84}$ But despite some temporary reversals, we contend that there has been a gradual transition from more direct spectator involvement towards more detached forms of support encompassing greater emphasis on visually experienced excitement. We argue that this transition, and the more fragile player civilizing process, is connected to broad figurational shifts.

\section{Figurations of Ireland}

As Elias argues, 'studies of sport which are not studies of society are studies out of context' ${ }^{85}$ Here, we attempt to provide the changing social context for the development of player and spectator conduct at hurling matches in Ireland. We argue that since the late nineteenth century the network of mutual dependencies affecting most people in Ireland became more extensive and all-pervasive. More and more people of diverse class positions had to succumb to a wider variety of social pressures to control themselves and attune their conduct according to specific power relations. However, these changes did not proceed evenly, though there was a specific order or structure to the changes.

As England in particular became more industrialized over the nineteenth century, a parallel functional specialization and social differentiation advanced in Irish agricultural production processes and structures. The greater division of labour involved farmers concentrating on specific crop cultivation or specific animal breeding (and often on different phases of animal lifespan). This brought small and subsistence farmers into a more extensive social figuration characterized by different phases of food production and distribution. ${ }^{86}$ The growing commercialization of agricultural functions led to the expansion of more social functions in towns and cities in the form of market exchanges and exporting facilities. The state became more concerned with effective transportation networks and the safe carriage of goods. Growing interdependencies between Irish producers and English and Irish consumers 
encouraged larger and more mechanized farms, which in turn led to considerable rural depopulation. Migration to towns (and emigration) to take up new social functions of administration and distribution increased. According to selected Census of Population statistics (1861 to 2002) the proportion of the male labour force engaged in agricultural occupations remained fairly stable at between $50 \%$ and $60 \%$ up to 1946 . From $43 \%$ in 1961 the proportion declined to $20 \%$ by 1981 and $8 \%$ by 2002 . We emphasize the agricultural labour force here because farming life is far more self-sufficient compared to the more socially complex urban life of industrial and post-industrial figurations. There were of course interdependencies between farmers themselves, and between farmers, landowners and consumers, but everyday life for farmers and agricultural labourers did not involve the numerous and frequent social constraints and compulsions that comprised the working and living conditions of people in towns and cities. As Elias notes, everyone comprising a figuration experiences different levels and types of constraint and pressure. ${ }^{87}$ Those occupying central positions and roles in the overall figuration must exert a more 'steady control of conduct' compared to those occupying peripheral positions. Thus, as well as urban-rural differences there are inter-class differences and dynamics within cities which affect habitus formation. Irish society towards the end of the nineteenth century had undergone a process of agrarian class transformation, ${ }^{88}$ whereby the axis of conflict and tension shifted from relations between farmers, landholders and labourers to those predominantly between farmers and landowners.

We argue that such a shift provided the tentative social conditions for the establishment of a rule-making and standardizing organization, namely the GAA. Declining violence and enmity between 'native', Catholic agrarian classes allowed attempts to pursue regular organization of games. More pronounced social tensions (between landowner and tenant-farmer) overlapped other group distinctions along ethnic and religious lines, giving the organization and connotations of hurling a particularly national and patriotic tone. The continuing high class barriers between tenants and mainly Protestant landlords loyal to the Union with Britain led to a symbolic realignment of the social acceptability of different sports which operated in an inter-related, dialectical spiral. Rugby, cricket and tennis became taboo for the 'true Gael'. Class barriers also sustained high degrees of enmity and violence between farmers and landlords up until the early twentieth century when various legislative acts secured farmer proprietorship of farms. The shifting power ratio between farmers and landlords, informed by the increasingly confident rhetoric of the Irish nation, was also echoed in the increasing fortunes of the urban working classes in respect of their employers. ${ }^{89}$ These groups too tended to be nationalistic, given that they were largely drawn from sons and daughters of farmers and agricultural labourers unable to secure meaningful social positions on farms due to the impartible inheritance tradition, ${ }^{90}$ and were allied to upwardly mobile middle classes composed of teachers, civil servants and clerks who were increasingly required in the context of greater social interdependencies. Members of these groups led the process of national 'independence' through violent challenges on the British state monopoly of violence. Partial success in 1919-21 was followed by the Irish Civil War of 19223. Therefore, violence continued to be a significant feature of Irish society well into 
the twentieth century, and indeed violent confrontations between members of the opposing groups in the Civil War persisted into the 1930s. ${ }^{91}$

The ambivalence to violence has been shaped by the parallel processes of the success of these social groups in securing a measure of autonomy from Britain through violent conflict, and the sense of failure and shame in the very partiality of that success - part of the Irish nation remained under British jurisdiction. 'Parliamentarization'92 did not proceed smoothly or evenly due to the incomplete project of the Irish nation-state, as well as the social and symbolic struggles over the means of its completion. Though successive governments gradually achieved a state monopoly of violence over its jurisdiction of 26 counties, this cannot be said for British control of the six north-eastern Irish counties that became known as 'Northern Ireland' since partition in 1920-1 (and hurling has been played and organized on all All-Ireland basis).

Though we have argued that farming life was more autarkic than urban life, we stress that farmers and labourers were still enmeshed in interdependent relationships (otherwise there would be no compulsion to resort to violence at all). However, farmers became more enmeshed in such relations through the twentieth century as the pressure to commercialize and forge multi-tiered cooperatives increased. ${ }^{93}$ Ireland's entry to the European Community in 1973 also brought new social pressures and opportunities to Irish farmers. ${ }^{94}$ Another indicator of increasing social interdependencies and denser figurations is urbanization; the proportion of the Irish nation-state population living in urban areas of more than 1,500 people rose from $32 \%$ to $52 \%$ between 1900 and $1971 .^{95}$ Urbanization within the state was an aspect of increasing social interdependencies within the Irish social figuration, and indeed between Irish and other societies. The expanding urban population led to greater pressure for meaningful social opportunities; violent conflict between employers and workers occasionally occurred. However, through the growth of trade unions, ${ }^{96}$ and in a reciprocal movement, the emergence of effective employer organizations, ${ }^{97}$ power relations between social classes became less unequal (though still asymmetric). These organizations representing sectional interests became multitiered social institutions with a new professional group of negotiators tasked with the more rational conclusion of agreements. As people living in towns and cities became immersed in more pacified relations, they came under greater social expectations and pressure to exert more even and stable self-control. The political economic situation in Ireland also became more expansive and outward looking as politicians sought to increase employment opportunities (and stem emigration - a source of shame to ideals of nationhood) through attracting foreign investment from the 1960s onwards. This again expanded social interdependencies and further enmeshed Irish people within a globalized system of production, exchange and consumption. The social figuration comprising Ireland and Britain remained highly asymmetrical up to the 1960 s, but an example of the lessening power ratio since then can be seen in the decreasing dependency of Irish exporters on the United Kingdom market. Exports to the UK as a proportion of total Irish exports declined from $93 \%$ to $33 \%$ between 1938 and $1985 .{ }^{98}$ Ireland had become much more enmeshed within a broader network of nation-states. Between 1951 and 1988, the proportion of exported manufacturing 
output increased from $16 \%$ to $64 \% .{ }^{99}$ By then, $44 \%$ of manufacturing employment was in foreign-owned companies which accounted for $75 \%$ of manufacturing exports. ${ }^{100}$

\section{Conclusion}

We argue that these social processes of increasing social interdependencies, differentiation and integration gradually placed greater constraints on spontaneous, violent emotional displays, which in turn inculcated in people less aggressive conduct while engaged in playing and watching hurling. However, due to the uneven, contradictory and, at times, reversing nature of such civilizing processes within the general development of growing social interdependencies, these changes in the culture of violence in sport have been fragile, ambivalent and non-linear. The growing commercialization of Irish farming over the course of the nineteenth century, in the context of continuing industrialization processes in England, represented greater social integration, in the economic sense, between Irish and English groups. This led to a declining power ratio between Irish tenant-farmers and landlords. However, given the continued social distance between these groups, the continuing conflict between them was often expressed violently. These cycles of violence tended to be temporarily subdued by UK government measures (such as peasant proprietorship), but the rising social power of Irish social groups coupled with cultural narratives of national self-determination meant violent struggles resurfaced. Hurling as a sport was thus represented militarily, and 'danger' was seen as one of its merits as opposed to the supposedly less masculine English sports. There was a contradictory but related double movement involving social pressures to less violent forms of sport, under processes of increasing social interdependency between Irish people, and a national pride in the distinctiveness of hurling in terms of the Irish capacity for displays of strength and defiance. Gradually however, violence on the field became more shameful, but this remained somewhat fragile due to both the uneven nature of Irish social development, and the structure of the game itself which stands for 'we-group' pride. Fast action on the field, the use of sticks to propel the ball at high speed, and close man-to-man marking are part of the specific game figuration. It is for this reason that violence among spectators has become more unacceptable; while it may be regretted that players still occasionally lose their tempers (and they have been placed under greater social scrutiny and moral opprobrium when this does occur), spectators are expected to control themselves to a much higher degree (and we argue that they have increasingly been able to do this). These are relative movements; spectators still look for excitement but by and large manage to control their urge to participate in play or attack referees and opposing players. Indeed this self-control of emotion for the duration of the game often leads to celebratory releases in the form of pitch invasions once the final whistle goes! In conclusion, our findings for the Irish sport of hurling support the merits of the figurational approach developed by Elias and Dunning; our main caveat (and this does not contradict their theories) is that more attention needs to be paid to specifying the complex and contradictory figurational dynamics of each nation-state, as all countries have followed unique trajectories. 
[1] Elias and Dunning, 'Dynamics of group sports with special reference to football'; Elias and Dunning, Quest for Excitement; Dunning and Sheard, Barbarians, Gentlemen and Players.

[2] see de Búrca, Michael Cusack and the GAA.

[3] Elias and Dunning, Quest for Excitement.

[4] Lennon, The Playing Rules of Football and Hurling, 1.

[5] Ibid.

[6] Ibid., 3.

[7] Ibid.

[8] Mandle, The Gaelic Athletic Association and Irish Nationalist Politics, 3.

[9] Ibid.

[10] quoted in de Búrca, Michael Cusack and the GAA, 83.

[11] Mandle, The Gaelic Athletic Association and Irish Nationalist Politics, 3.

[12] Lennon, The Playing Rules of Football and Hurling, 11.

[13] Celtic Times, 16 April 1887, 6.

[14] Mandle, The Gaelic Athletic Association and Irish Nationalist Politics, 95.

[15] Ibid., 150.

[16] Lennon, The Playing Rules of Football and Hurling, 46.

[17] Ibid., 72.

[18] Ibid., 99.

[19] Elias, Time.

[20] Lennon, The Playing Rules of Football and Hurling, 199.

[21] Kee, The Green Flag, 643-4.

[22] Ibid., 680, 708.

[23] Elias, 'Introduction'.

[24] Curry et al, 'Sociological versus Empiricist History,' 113 note the difficulty in quantifying violence in sport.

[25] see Elias, The Civilizing Process.

[26] Lennon, The Playing Rules of Football and Hurling, 1.

[27] Goudsblom cited in Wouters, 'Developments in the Behavioural Codes between the Sexes', 422.

[28] see Dunning, 'Social Bonding and Violence in Sport'.

[29] Lennon, The Playing Rules of Football and Hurling, 2.

[30] Croke quoted in Fullam, The Throw-In, 44-5.

[31] see Elias and Dunning, Quest for Excitement.

[32] see de Búrca, Michael Cusack and the GAA, 149-64.

[33] Celtic Times, 7 May 1887.

[34] see Elias, The Society of Individuals.

[35] Kee, The Green Flag, 364-75; Lee, The Modernisation of Irish Society, 65-96.

[36] see Elias, The Society of Individuals; The Civilizing Process.

[37] Celtic Times, 7 May 1887.

[38] McDevitt, 'Muscular Catholicism'. 
[39] Celtic Times, 26 February 1887.

[40] Ibid., 7 May 1887.

[41] see de Búrca, Michael Cusack and the GAA.

[42] Celtic Times, 9 April 1887.

[43] see de Búrca, Michael Cusack and the GAA, 162.

[44] Lennon, The Playing Rules of Football and Hurling, 35.

[45] Mandle, The Gaelic Athletic Association and Irish Nationalist Politics, 76.

[46] Ibid., 79.

[47] Lennon, The Playing Rules of Football and Hurling, 52.

[48] Ibid., 237.

[49] Gaelic Athletic Association, GAA Official Guide, 39.

[50] Downey, Irish Times, 11 July 1977.

[51] Lennon, The Playing Rules of Football and Hurling, 86.

[52] McCarthy quoted in Mandle, The Gaelic Athletic Association and Irish Nationalist Politics, 162.

[53] Kee, The Green Flag, 693.

[54] Mandle, The Gaelic Athletic Association and Irish Nationalist Politics, 162.

[55] Ibid., 174.

[56] Irish Press, 7 August 1933.

[57] Ibid., 17 August 1936.

[58] Ibid., original emphasis.

[59] Lennon, The Playing Rules of Football and Hurling, 273.

[60] Ibid., 274.

[61] Ibid., 307.

[62] McCarthy, Irish Press, 5 August 1974.

[63] Moran, Irish Times, 20 July 1998.

[64] Ibid., 22 July 1998.

[65] McIntyre, Galway City Tribune, 24 December 1986; Moran, Irish Times, 22 July 1998.

[66] GAA Central Council minutes, 10 August 1946.

[67] Murphy cited in O’Sullivan, Men in Black, 122.

[68] Flynn et al, 'Ocular Injury in Hurling', 495.

[69] see Sheard, 'Boxing in the Western Civilizing Process'.

[70] McIntyre, Galway City Tribune, 24 December 1986.

[71] Elias, The Civilizing Process, 171.

[72] Lennon, The Playing Rules of Football and Hurling, 1.

[73] de Búrca, Michael Cusack and the GAA, 83.

[74] Lennon, The Playing Rules of Football and Hurling, 20.

[75] Celtic Times, 7 May 1887.

[76] Lennon, The Playing Rules of Football and Hurling, 52.

[77] Irish Press, 7 August 1933.

[78] Ibid.

[79] Irish Press, 17 August 1936.

[80] Elias, Involvement and Detachment, 45-115. 
[81] Lennon, The Playing Rules of Football and Hurling, 220.

[82] Irish Press, 24 July 1950.

[83] Downey, Irish Times, 3 July 1989.

[84] Ibid.

[85] Elias, 'Introduction', 26.

[86] see Clark, 'The Importance of Agrarian Classes', 31; Ó Gráda, Ireland, 255-70.

[87] Elias, The Civilizing Process, 380.

[88] see Clark, 'The Importance of Agrarian Classes'.

[89] see Keogh, The Rise of the Irish Working Class.

[90] Lee, The Modernisation of Irish Society, 3-4.

[91] Lee, Ireland 1912-1985.

[92] Elias, 'Introduction'.

[93] Jones, 'Divisions within the Irish Government over Land-Distribution Policy, 194070 '.

[94] see Lee, Ireland 1912-1985, 491-2.

[95] Vaughan and Fitzpatrick, Irish Historical Statistics.

[96] see Keogh, The Rise of the Irish Working Class; Roche, 'The Liberal Theory of Industrialism and the Development of Industrial Relations in Ireland'.

[97] McGuire, in FIE: Federation of Irish Employers.

[98] Kennedy et al, The Economic Development of Ireland in the Twentieth Century.

[99] O'Malley, 'Problems of Industrialisation in Ireland', 33-4.

[100] Ibid., 39.

\section{References}

de Búrca, M. Michael Cusack and the GAA. Dublin: Anvil Books, 1989.

Clark, S. "The Importance of Agrarian Classes: Agrarian Class Structure and Collective Action in Nineteenth-Century Ireland." British Journal of Sociology 29, no. 1 (1978): $22-40$.

Curry, G., E. Dunning, and K. Sheard. "Sociological Versus Empiricist History: Some Comments on Tony Collins's 'History, Theory and the "Civilizing Process"." Sport in History 26, no. 1 (2006): 110-23.

Dunning, E. "Social Bonding and Violence in Sport." In Quest for Excitement: Sport and Leisure in the Civilizing Process, edited by N. Elias and E. Dunning. Oxford: Blackwell, 1986: 224-44.

Dunning, E., and K. Sheard. Barbarians, Gentlemen and Players: A Sociological Study of the Development of Rugby Football. 2nd ed. London and New York: Routledge, 2005.

Elias, N. The Civilizing Process: Sociogenetic and Psychogenetic Investigations. Translated by E. Jephcott. Revised ed. Oxford: Blackwell Publishers, 2000.

Elias, N. "Introduction." In Quest For Excitement: Sport and Leisure in the Civilizing Process, edited by N. Elias and E. Dunning. Oxford: Blackwell, 1986: 19-62.

Elias, N. Involvement and Detachment. Translated by E. Jephcott. Oxford: Basil Blackwell, 1987. 
Elias, N. The Society of Individuals. Translated by E. Jephcott. Oxford: Basil Blackwell, 1991.

Elias, N. Time: An Essay. Translated by E. Jephcott. Oxford: Blackwell Publishers, 1993.

Elias, N., and E. Dunning. "Dynamics of Group Sports with Special Reference to Football." British Journal of Sociology 17, no. 4 (1966): 388-402.

Elias, N., and E. Dunning, eds. Quest For Excitement: Sport and Leisure in the Civilizing Process. Oxford: Blackwell, 1986.

Flynn, T. H., K. Fennessy, N. Horgan, B. Walsh, E. O'Connell, P. Cleary, and S. Beatty. “Ocular Injury in Hurling." British Journal of Sports Medicine 39 (2005): 493-96.

Fullam, B. The Throw-In: The GAA and the Men who Made It. Dublin: Wolfhound Press, 2004.

Jones, D. S. "Divisions within the Irish Government over Land-Distribution Policy, 194070." Éire-Ireland 36, no. 3/4 (2001): 83-110.

Kee, R. The Green Flag: A History of Irish Nationalism. London: Penguin, 2000.

Kennedy, K. A., T. Giblin, and D. McHugh. The Economic Development of Ireland in the Twentieth Century London: Routledge, 1988.

Keogh, D. The Rise of the Irish Working Class: The Dublin Trade Union Movement and Labour Leadership, 1890-1914. Belfast: Appletree Press, 1982.

Lee, J. Ireland 1912-1985: Politics and Society. Cambridge: Cambridge University Press, 1989.

Lee, J. The Modernisation of Irish Society: 1848-1918. Dublin: Gill and Macmillan, 1989.

Lennon, J. The Playing Rules of Football and Hurling, 1884-1995. Gormanstown, Co. Meath: Northern Recreation Consultants, 1997.

Mandle, W. F. The Gaelic Athletic Association and Irish Nationalist Politics, 1884-1924. Dublin: Gill and Macmillan, 1987.

McDevitt, P. F. "Muscular Catholicism: Nationalism, Masculinity and Gaelic Team Sports, 1884-1916." Gender \& History 9, no. 2 (1997): 262-84.

McGuire, E. A. In FIE: Federation of Irish Employers, 1942-1992, edited by B. Chubb. Dublin: Gill and Macmillan, 1992: 48-53.

O'Malley, E. "Problems of Industrialisation in Ireland." In The Development of Industrial Society in Ireland, edited by J. H. Goldthorpe and C. T. Whelan. Oxford: Oxford University Press, 1992: 31-52.

O’Sullivan, J. Men in Black. Dublin: Sliabh Bán Publications, 2002.

Ó Gráda, C. Ireland: A New Economic History. Oxford: Oxford University Press, 1994.

Roche, W. K. "The Liberal Theory of Industrialism and the Development of Industrial Relations in Ireland." In The Development of Industrial Society in Ireland, edited by J. H. Goldthorpe and C. T. Whelan. Oxford: Oxford University Press, 1992: 291-327.

Sheard, K. "Boxing in the Western Civilizing Process." In Sport Histories: Figurational Studies of the Development of Modern Sports, edited by E. Dunning, D. Malcolm and I. Waddington. London and New York: Routledge, 2006: 15-30.

Vaughan, W. E., and A. J. Fitzpatrick, eds. Irish Historical Statistics: Population, 18211971. Dublin: Royal Irish Academy, 1978. 
Wouters, C. "Developments in the Behavioural Codes between the Sexes: The Formalization of Informalization in the Netherlands, 1930-85." Theory, Culture \& Society 4, no. 2/3 (1987): 405-27. 